\title{
Nonequilibrium grain boundaries in bulk nanostructured metals and their recovery under the influences of heating and cyclic deformation. Review
}

\author{
A. A. Nazarov ${ }^{\dagger}$ \\ †aanazarov@imsp.ru \\ Institute for Metals Superplasticity Problems of RAS, 39 Khalturin st., Ufa, 450001, Russia
}

\begin{abstract}
Bulk nanostructured, or ultrafine-grained (UFG) metals and alloys produced by severe plastic deformation (SPD) methods have grain boundaries (GBs), which are in a specific, non-equilibrium state associated with extrinsic grain boundary dislocations (EGBDs) introduced into the boundaries during deformation. In the present review, the origin of this state is analyzed basing on the results of studies of large plastic deformations, according to which during straining the GBs accumulate mesodefects consisting of Rybin disclinations at triple junctions and tangential EGBD arrays and inherit them after removing the load. The main experimental evidences of the nonequilibrium character of GBs in as-prepared nanostructured materials are presented. Main ideas and results of the structural model of UFG metals based on the physics of dislocations and disclinations are overviewed. The latest works on molecular dynamics simulations carried out to explore the detailed atomic structure of disclinations and nonequilibrium GBs are considered and their results are compared to the predictions of the structural model. Mechanisms and kinetics of diffusion controlled recovery of nonequilirium GBs are described. An alternative mechanism of athermal relaxation of nonequilirium GB structure under the action of oscillating stresses has been most recently discovered and elucidated experimentally and by means of computer simulations. The main results of these studies are shortly reviewed too.
\end{abstract}

Keywords: bulk nanostructured material, ultrafine grained material, severe plastic deformation, grain boundary, dislocation, Rybin disclination, molecular dynamics.

УДК: 548.4:620.186.8

\section{Неравновесные границы зерен в объемных наноструктурных материалах и их возврат под влиянием нагрева и циклической деформации. Обзор}

\author{
Назаров А. А. ${ }^{\dagger}$ \\ Институт проблем сверхпластичности металлов РАН, ул. Халтурина, 39, Уфа 450001, Россия
}

\begin{abstract}
Объемные наноструктурные, или ультрамелкозернистые (УМЗ) материалы, полученные методами интенсивной пластической деформации (ИПД), содержат границы зерен (ГЗ), находящиеся в специфическом, неравновесном состоянии, связанном с внесенными зернограничными дислокациями (ВЗГД), введенными в границы при деформации. В настоящем обзоре проанализирована природа этого состояния на основе результатов исследований больших пластических деформаций, согласно которым при деформировании ГЗ накапливают мезодефекты, состоящие из дисклинаций Рыбина в тройных стыках и системы тангенциальных дислокаций, и наследуют их после снятия нагрузки. Приведены основные экспериментальные доказательства неравновесного характера ГЗ в свежеприготовленных наноструктурных материалах. Сделан обзор основных идей и результатов структурной модели УМЗ металлов, основанной на физике дислокаций и дисклинаций. Рассмотрены недавние работы по молекулярно-динамическому моделированию, выполненные для исследования атомной структуры дисклинаций и неравновесных ГЗ, и их результаты сопоставлены с предсказаниями структурной модели. Описаны механизмы и кинетика диффузионно-контролируемого возврата неравновесных ГЗ. Совсем недавно был открыт альтернативный механизм атермической релаксации неравновесной структуры ГЗ под действием осциллирующих напряжений и исследован экспериментально и методом компьютерного моделирования. Сделан краткий обзор основных результатов этих исследований.
\end{abstract}

Ключевые слова: объемный наноструктурный материал, ультрамелкозернистый материал, интенсивная пластическая деформация, граница зерен, дислокация, дисклинация, молекулярная динамика. 


\section{Introduction}

One of the most common processes occurring in polycrystalline materials during plastic deformation is the interaction of grain boundaries (GBs) with lattice dislocations, which results in a specific, high energy state of the GBs commonly referred to as a nonequilibrium state [1-4]. This state is caused by the presence of extrinsic grain boundary dislocations (EGBDs), which introduce perturbations in the atomic structure of GBs and induce long-range stresses near them [2-5].

Starting from pioneering works of 1990-ths, numerous studies have demonstrated that nonequilibrium GB structure is typical for bulk ultrafine grained (UFG) and nanostructured materials, in particular for the ones processed by severe plastic deformation (SPD) methods [6,7]. As such, it is considered to affect the mechanical and physical properties of these advanced materials. Results of the studies of nonequilibrium grain boundaries (NGBs) and their role in the properties of UFG materials have been overviewed in a number of books and reviews [6-13]. Meanwhile, however, significant advances have been achieved in this field in the last few years. In particular, the first atomistic simulations of NGBs have been carried out [14-19], and a new mechanism of structure relaxation in these boundaries associated with ultrasonic treatment has been discovered [20-30]. The present review is an attempt to incorporate these new results into the existing knowledge on NGBs and evaluate a potential impact of the new knowledge to the studies of structure-property relations in bulk UFG materials.

\section{Basic notions on the formation of nonequilibrium grain boundaries during deformation processing}

In general, various types of the nonequilibrium structure of GBs can exist. For example, GBs having excess free volume due to absorbed vacancies or a disordered atomic structure formed after processing can be considered as nonequilibrium ones, since they have an enhanced energy and can relax during heating. NGBs of this type have been studied by molecular dynamics (MD) simulations in [31-33]. The distinctive feature of this type of nonequilibrium is that it results only in short-range stresses near the boundaries and their relaxation involves displacements of atoms only on the atomic scale. For this reason, their effect on the properties of nanocrystals can be very limited. On contrary, NGBs containing EGBDs induce long-range stress fields and, as it will be demonstrated below in Sections 6 and 7, their recovery requires processes occurring on the scale of grain size. Thus, our attention below will be focused on this type of nonequilibrium, which is fundamentally different from the others.

Origin of NGBs was most clearly elucidated by Rybin and co-workers who studied experimentally and theoretically the structure evolution during large plastic deformation [34-36]. They showed that GBs, being strong barriers for slip propagation, accumulated dislocations arising due to a mismatch of the strains of neighboring grains, which had different orientations with respect to the loading direction and were deformed by dislocation glide on different sets of slip systems. These dislocations form specific EGBD systems, which can be conventionally divided into two types of mesodefects composed of dislocations with Burgers vectors normal and tangential to the GB planes. The former are described by means of disclinations located on grain junction lines and are called junction disclinations [34-37]. In order to distinguish this notion of junction disclinations from other, not always correct, interpretations, we will further call them also Rybin disclinations. Rybin disclinations are rotational defects, which arise due to the mismatch of misorientations of boundaries meeting at the junctions and have been shown to be main drivers of grain subdivision into fragments, since, on accumulating a certain level of their strength, the disclinations originate broken dislocation boundaries growing from the junctions into the grains. This is the fundamental basis of grain refinement by SPD processing [35].

Grain subdivision models based on Rybin's concept were considered in [38-40]. In [38,39], an energetic criterion was used, according to which splitting of a grain can occur by the formation of new boundaries, if it results in an energy gain with respect to the energy of a system of junction disclinations. The grain splitting model based on this consideration was implemented in visco-plastic self consistent (VPSC) simulations and successfully used to describe the process of grain subdivision and texture evolution during large shear deformation [40].

More recently, extensive direct two-dimensional dislocation dynamics simulations of the fragmentation process have been carried out [41-44]. These studies have confirmed that Rybin disclinations play a key role in the grain subdivision process resulting in a self-organization of dislocations into new misorientation boundaries. Moreover, the formation of partial disclinations in strain gradients during large shear deformation was directly demonstrated in MD simulations [45].

As far as SPD processing assumes an application of very large, but finite strains, after the removal of deformation load the microstructure of material inherits the defects induced by straining all but some amount of dislocations, which can move under the action of internal stresses and annihilate or sink somewhere. Therefore, the main part of defects accumulated in GBs will remain there resulting in a NGB structure in an as-processed UFG material.

\section{Experimental evidences of nonequilibrium grain boundary structure in ultrafine grained materials}

Experimental evidences of the nonequilibrium structure of GBs in SPD-processed UFG materials are very diverse. The very first confirmations came from electron microscopic observations, which showed a specific, strain contrast consisting of extinction contours from GBs in as prepared UFG materials as opposed to the band contrast from GBs in well annealed metals [6,7]. This contrast was interpreted as an indication on the presence of high internal stresses in these materials. Since the density of lattice dislocations in UFG materials is usually low, these internal stresses were suggested to arise from the NGBs, which were formed 
during severe deformation. Moderate annealing resulted in the relaxation of the GB structure that did not involve any significant grain growth. The extinction contours in the grains disappeared, and the GBs acquired their usual band contrast. An example of such a behavior is presented in Fig. 1 [11].

The fact that the internal stresses observed are induced by GBs is confirmed by direct high-resolution transmission electron microscopic (HRTEM) observations of several SPDprocessed nanostructured metals and alloys [46-48]. It is worth of noting that in [46] an ingenious method of artificial Moiré pattern formation by superimposing a perfectly periodic grid printed on a transparent film on HREM images was used in order to visualize and measure the lattice distortions in nanocrystalline $\mathrm{Ni}_{3} \mathrm{Al}$. As we will see below in Section 5, the same method can be used to visualize lattice distortions in computer simulated nanocrystals with NGBs.

Quite recently, a new method of strain mapping based on HRTEM has been used to analyze the defect content of a triple junction in nanocrystalline $\mathrm{Pd}$ and the existence of a disclination on this junction has been directly proved [49].

$\mathrm{X}$-ray diffraction studies of bulk nanostructured materials have shown that root mean square (rms) microstrains in these materials can be as high as tenths of percent and depend on the method of processing used and post-processing storage conditions $[10,11,50-52]$. In nanocrystalline $\mathrm{Ni}_{3} \mathrm{Al}$ prepared by SPD rms strain of $1 \%$ was observed [53].

Enhanced energy of GBs in UFG materials is measured in differential scanning calorimetric (DSC) studies, which detect an energy release in a temperature range, where no significant grain growth occurs, that can be interpreted to occur due to the relaxation of NGBs [53-55]. In [56], measurements of GB dihedral angles by means of scanning tunneling microscopy were used to study the distribution of GB energies in UFG copper and nickel processed by equalchannel angular pressing (ECAP). These studies have shown that in the as-prepared state GBs have higher energies, while with annealing the distribution of GB energies becomes narrower, energies of GBs decrease.

More evidences have been obtained by extensive studies of mechanical and physical properties such as elastic moduli,

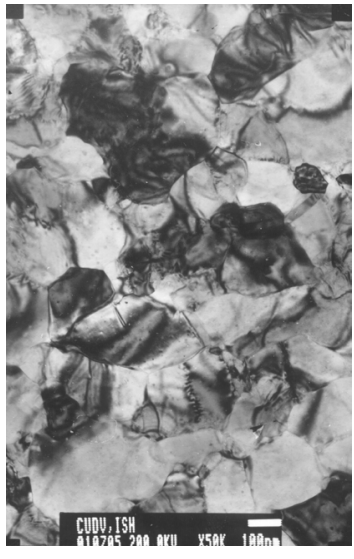

a

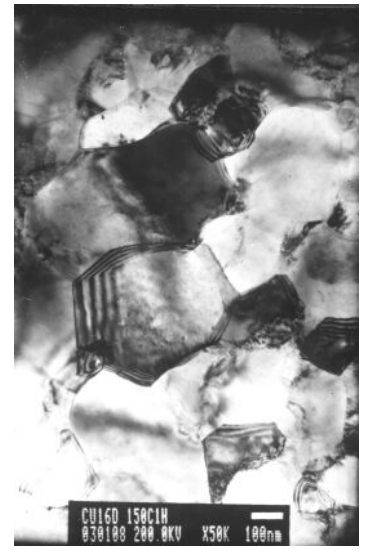

b
Fig. 1. Transmission electron micrographs of nanostructured $\mathrm{Cu}$ processed by high pressure torsion: the as-prepared state (a); after annealing at $150^{\circ} \mathrm{C}(\mathrm{b})$. internal friction, electric and magnetic properties, which in as-prepared UFG materials are significantly modified as compared to their coarse grained counterparts and recover usual values upon annealing [6-8]. Diffusion coefficient is a characteristic particularly sensitive to the GB atomic structure. Several studies showed that UFG metals processed by high-pressure torsion (HPT) and ECAP possessed GB diffusion coefficient several orders of magnitude higher than in coarse-grained polycrystals and recovered ordinary values on annealing [57-59]. It should be noted, however, that quantitative results on the diffusion coefficient enhancement in UFG metals are still controversial. Wilde and co-workers $[60,61]$ studied the diffusion coefficient in UFG nickel and copper processed by ECAP and found that in these materials ultra-fast diffusion paths were formed due to percolating porosity along triple junctions. Application of back pressure during ECAP and processing by HPT, which also suppresses the formation of pores and cracks, results in a much lower diffusion coefficient [61]. Therefore, the change of GB diffusion coefficient is greatly related to processing regimes. Determining the intrinsic behavior of GB diffusion in UFG metals is still a problem, which, probably, can be addressed by molecular dynamics simulations.

\section{Structural model of SPD-processed bulk nanostructured materials}

The key points of dislocation and disclination based structural model of SPD-processed materials are explained as follows.

Consider an idealized model of polycrystal depicted in Fig. 2a. Let the polycrystal be deformed by tension as indicated by arrows under the applied stress. Let, for convenience, only two grains symmetrically oriented with respect to the tension axis, be deformed by glide of dislocations on a single slip plane. Such a simplified model is presented here, since, as discussed in Section 5, it can be most conveniently used for atomistic simulations of NGBs [18]. Since dislocation glide is limited by GBs, each grain supplies to its boundaries a system of dislocations, which are coupled into dipoles and have the total Burgers vector equal to zero. If one decomposes dislocations in each GB to the ones with Burgers vectors normal and parallel to boundary planes, one will obtain two subsystems: arrays of tangential EGBDs and those of normal EGBDs represented by means of Rybin disclinations (Fig. 2b). This subdivision following the ideas by Rybin et al. [34-36] was used in [62-64] to model the structure of SPDprocessed UFG metals. Apart from these components, one more component of the NGB structure was proposed, which consisted in a generally disordered distribution of EGBDs in each GB [65] and had been shown to result in long-range stress fields of GBs $[4,66]$. However, further studies have shown that in the most of UFG metals except for refractory ones this component can relax at room temperatures [67], thus they should not be as significant as the above mentioned two components.

In order to make the model analytically tractable, a simpler nanocrystal, in which the grains have a square parallelepiped shape, was considered in [62-64]. Basing on linear elasticity theory of dislocations [68] and disclinations [69], rms elastic 
strains and excess GB energies were estimated as functions of the rms strength of disclinations, $<\Omega^{2}>^{1 / 2}$, and rms density of tangential dislocations (Burgers vector per unit GB length), $\left\langle\beta^{2}\right\rangle^{1 / 2}$. The results of these estimates are collected in Table 1 , where $G$ is the shear modulus, $v$ the Poisson's ratio and $d$ the grain size.

It is important to note that the excess GB energy due to both types of mesodefects increases quadratically with the strength of disclinations and density of EGBDs. This is typical for dislocation and disclination type defects $[68,69]$.

Numerical estimates in $[62-64]$ were made for "reasonable" values of the strength of defects $\left.<\Omega^{2}\right\rangle^{1 / 2} \approx$ $\left\langle\beta^{2}\right\rangle^{1 / 2} \approx 0.02$ and $\mathrm{rms}$ strains of the order of $1 \%$ and GB excess energies of the order of $1 \mathrm{Jm}^{-2}$ were found that is in a satisfactory agreement with experimental data. It should be pointed out, however, that quantitative comparisons of calculated rms strains with the experimental data can be done with a great caution, since there is no direct correspondence between the scheme of calculating this quantity and experimental determination; moreover, the measurements of rms strains are generally based on different methods and can result in different values. Also, there is not enough experimental information on the parameters of mesodefects due to the difficulties of their experimental measurements. For this reason, computer simulations aimed at estimating the limiting densities of EGBDs seem to be important.

\section{Atomistic simulations of disclinations and non-equilibrium grain boundaries}

First MD simulations of disclinations were carried out in [70,71] using two-dimensional models of perfect disclinations. These studies indicated on the possibilities of energetically favorable amorphization at or dislocation emission from the disclination cores.

Three-dimensional MD simulations of partial disclinations were carried out in several works [72-76]. In these works, single negative disclinations with different strength values in cylindric bicrystals and tricrystals of nickel and titanium were studied. It was found that for any radius of the cylinders, a critical disclination strength existed above which it resulted in a nanocrack or pore formation at the disclination core. This critical strength decreases with an increase of the radius of cylinder. For nickel, it can be estimated from the following equation:

$$
\omega_{\mathrm{c}} \approx 55.7^{\circ} / \sqrt{R},
$$

where $R$ is substituted in nanometers [72]. Given the fact that the stress fields of disclinations in polycrystals scale with the grain size $d$, the latter can be substituted into Eq. (1) to estimate the upper limit of disclination strengths. This gives the values $4 \div 5^{\circ}$ for grain sizes about $d=100 \div 200 \mathrm{~nm}$.

Due to the Frank's vector conservation law for disclinations, nanocracks or pores, which open near the cores of overcritical disclinations, can continue from junction to junction. This can explain the formation of a percolating porosity in UFG metals observed in $[60,61]$.

A more realistic model of NGBs containing dipoles of partial disclinations was considered in [15-17]. In these works, wedge disclination dipoles were introduced into [112] tilt GBs in Ni. Such a system is very convenient for studies, since it allows for generation and movement of straight edge dislocations of only one slip system with the lines parallel to the tilt axis. A map of atomic energies calculated by molecular dynamics clearly showed that the NGB induced long-range stresses [16].

Quite recently, an even more realistic atomistic model of nanocrystalline f.c.c. metals with NGBs has been proposed $[18,19]$. The computational cell in this model consisted of four columnar grains with the column axis [112] so that the GBs between them were all [112] tilt GBs. A special method of construction has been proposed to introduce EGBDs in GBs in this nanocrystal. In order to form EGBDs on the boundaries of a selected grain, it is assumed to be removed from its place, freely deformed by dislocation glide, then
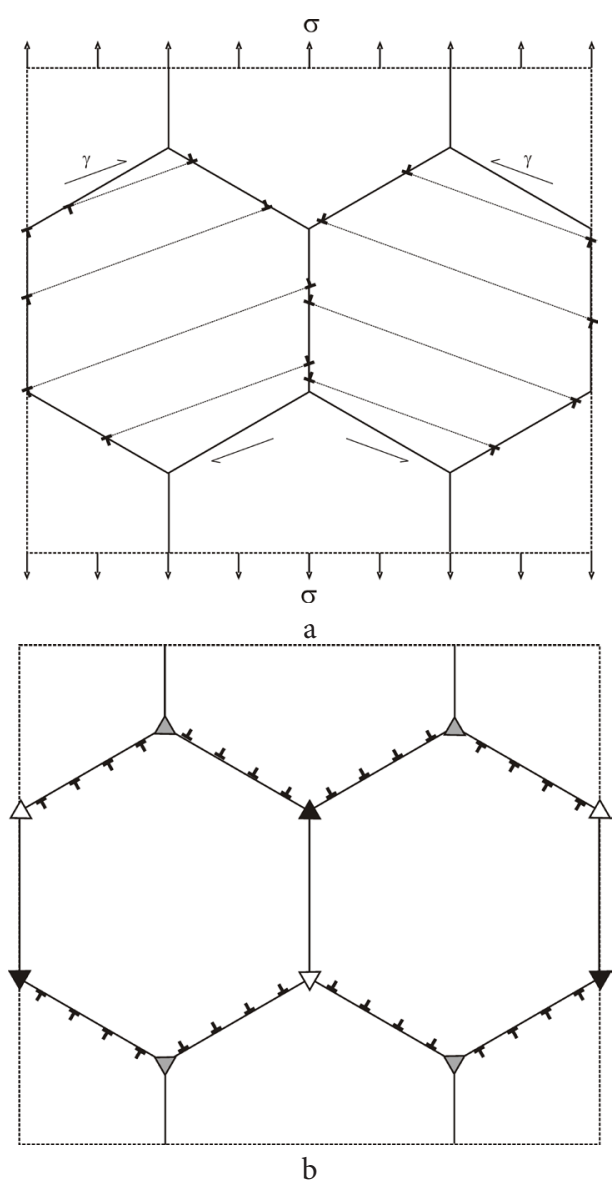

Fig. 2. Schematic representation of the trapping of lattice dislocations by grain boundaries during plastic deformation (a) and resulting components of the NGB structure (b). White and black triangles in (b) denote negative and positive disclinations, respectively.

Table 1. Rms strain and excess energy of NGBs due to Rybin disclinations and tangential EGBD arrays in a nanocrystal

\begin{tabular}{|c|c|c|}
\hline NGB component & Rybin disclinations & Tangential EGBD arrays \\
\hline Rms strain & $\varepsilon_{i}^{d} \approx 0.1<\Omega^{2}>^{1 / 2}$ & $\varepsilon_{i}^{\tau} \approx 0.3<\beta^{2}>^{1 / 2}$ \\
\hline $\begin{array}{c}\text { Excess energy } \\
\text { per GB unit area }\end{array}$ & $\gamma_{e x}=\frac{G<\Omega^{2}>d \ln 2}{16 \pi(1-v)}$ & $\gamma_{e x}=\frac{G<\beta^{2}>d(\pi-2 \ln 2)}{4 \pi(1-v)}$ \\
\hline
\end{tabular}


strained back elastically and embedded into the polycrystal. Then the system with EGBD precursors is subjected to energy minimization with special precautions preventing the EGBDs' annihilation. The geometry of the computational cell used in $[18,19]$ and created EGBD system are schematically presented in Fig. 2a.

An energy map of a nanocrystal with EGBDs and the corresponding energy scale are given in Figs. 3a,b. One can see that inside the grains of the nanocrystal there are high energy atoms that is an indication of high internal long-range stresses.

Interestingly, lattice distortions caused by the EGBDs can be easily visualized using Moiré patterns as in the case of HREM images [46]. In the present case, these patterns can form due to a superposition of the nanocrystalline lattice images onto the perfectly periodic lattice made by the computer screen pixels. Such a pattern obtained by an appropriate vizualization of the atomic structure corresponding to the energy map of Fig. $3 \mathrm{a}$ is presented in Fig. 3c.

\section{Diffusion controlled grain boundary recovery}

The nonequilibrium structure of GBs is a metastable, high energy one and relaxes towards equilibrium, if overcoming of energy barriers preventing the mobility of atoms becomes possible. One of the most general ways of providing this possibility is annealing, which allows for significant GB diffusion. The process of relaxation of NGB structure usually referred to as the grain boundary recovery is very important for the stability of the structure and properties of UFG materials and in particular for high-temperature deformation and superplasticity.
The GB recovery in UFG metals was studied on the basis of dislocation modeling in [77,78]. This process is controlled by the removal of EGBDs from GBs to neighbor boundaries through triple junctions that in general requires the GB diffusion. According to the models, relaxation of EGBD arrays of the two types, which have been described above in Sections 2 and 4, occurs as follows (Fig. 4). Sessile EGBDs, which constitute the dislocation content of junction disclinations, under mutual repelling forces sequentially approach the junctions and energetically favorably dissociate there into two EGBDs whose Burgers vectors lie on corresponding GBs (Fig. 4a). These dislocations easily leave the junctions by glide to annihilate with opposite dislocations somewhere at the centers of corresponding GBs. Therefore, the process of annealing of sessile EGBD arrays is controlled by a climb of the dislocations to triple junctions. Gliding EGBDs form a pile-up at triple junctions (Fig. 4b). Here the lead dislocations dissociate into two EGBDs with Burgers vectors normal to the planes of two neighboring GBs, which can now leave the junction by pure climb.

In a limit of an infinitesimal Burgers vector of the dislocations, one deals with a continuous diffusion model, in which the stresses of EGBDs are relaxed by diffusion of vacancies from dilated GB zones to compressed ones (the corresponding directions of vacancy flow are indicated by dotted arrows in Figs. $4 \mathrm{a}, \mathrm{b}$ ). In both cases, the recovery process requires diffusion to distances scaling with the GB length, i.e. the grain size. Accurate calculations based on the continuum GB diffusion and discrete dislocation analyses have shown that both models are characterized by an exponential law of time dependence of the average EGBD density:

$$
\Omega=\Omega_{0} \exp \left(-t / t_{0}\right), \quad \beta=\beta_{0} \exp \left(-t / t_{0}\right),
$$

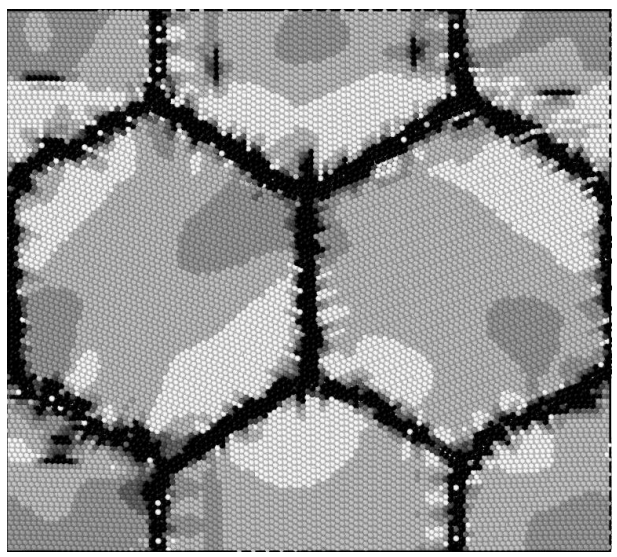

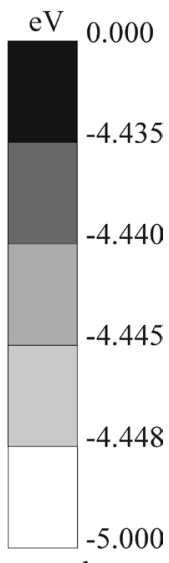

$\mathrm{b}$

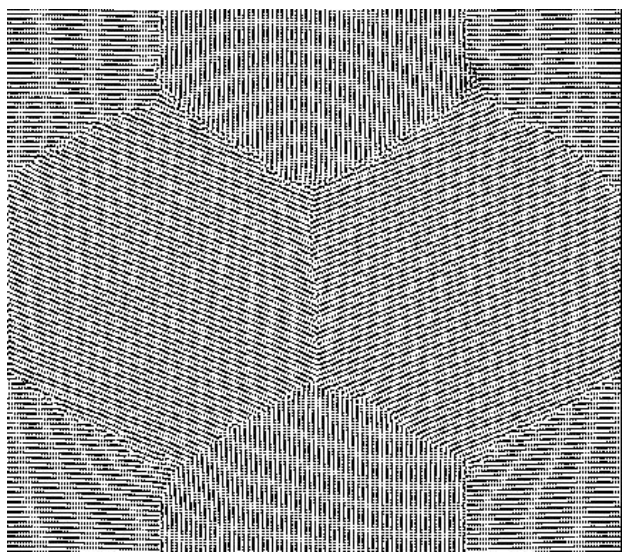

c

Fig. 3. Atomic energy map of a nanocrystal with NGBs containing EGBDs (a) with corresponding energy scale (b) and a Moiré pattern indicating the distortions of crystal lattice in the grains (c).

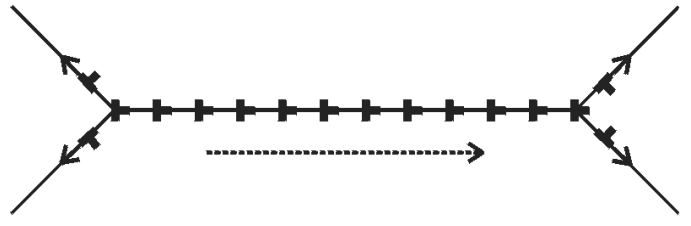

a

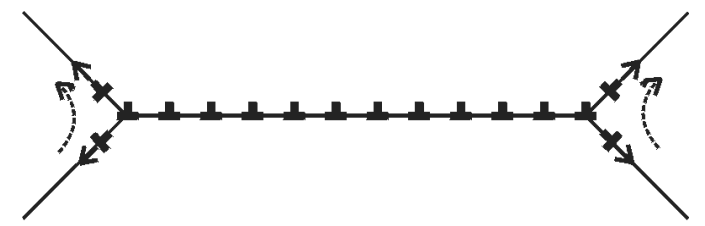

$\mathrm{b}$

Fig. 4. Mechanism of relaxation of normal EGBD arrays (junction disclination dipoles) (a) and tangential EGBD arrays (b). 
with a characteristic time approximately equal to

$$
t_{0} \approx \frac{d^{3} k T}{100 \delta D_{b} G V_{a}}
$$

where $d$ is the grain size, $\delta D_{b}$ is the GB diffusion width times GB self-diffusion coefficient and $V_{a}$ is the atomic volume.

For pure UFG $\mathrm{Cu}$ a significant relaxation of the structure and properties occurs during 1 hour annealing at a temperature $T=400 \mathrm{~K}[6,7]$. A calculation of the characteristic relaxation time according to Eq. (3) by using the parameter values $\delta D_{b 0}=2.35 \times 10^{-14} \mathrm{~m}^{3} / \mathrm{s}, \quad Q_{b}=107.2 \mathrm{~kJ} / \mathrm{mole}$ [79], $G=5 \times 10^{4} \mathrm{MPa}, V_{a}=1.18 \times 10^{-29} \mathrm{~m}^{3}$ gives a value of $t_{0}=60 \mathrm{~min}$, which is in excellent agreement with the experimental data.

\section{Relaxation of nonequilibrium grain boundaries induced by cyclic straining}

The GB recovery driven by diffusion is not the only possible way of relaxation of NGBs. In principle, EGBDs can be removed from GBs by external forces caused by an applied stress.

There have been several studies on the effect of mechanical loading on the nonequilibrium structure of GBs having a non-EGBD nature. In [31] the authors noted that plastic deformation of nanocrystals as-constructed by Voronoi tessellation resulted in a reduction of the number of atoms having coordination numbers less than 12 like annealing. This means that ordering of the GB atomic structure occurred. In [33] a relaxation effect of cyclic loading on the atomic structure and energy of nanocrystals constructed by the same method was found.

The effect of cyclic loading on the structure of NGBs containing EGBDs, which are typical for SPD-processed nanostructured materials, was studied recently in [15-19]. The idea behind these studies is as follows. EGBDs induce high internal stresses, which in the absence of applied load are in a mechanical equilibrium. When an external stress is applied and at some place has the same sign as internal one, it can activate there an emission of dislocations from GBs resulting in a decrease of their dislocation charge. If the applied stress oscillates symmetrically, the unidirectional internal stresses introduce an asymmetry into this dislocation emission process, i.e. an irreversible GB relaxation can occur. Moreover, if the applied stress amplitude is reasonably low, there will be no macroscopic plastic deformation of material and the only effect of cyclic loading will be the structural modification.

Indeed, a series of experimental studies have been obtained in the last decade, which gave the evidence of a significant relaxation effect of ultrasonic treatment (UST) on the structure of GBs in SPD-processed UFG metals.

In the first study [20] it was shown that oscillating tension-compression stresses with amplitudes in the range $40 \div 140 \mathrm{MPa}$ resulted in a decrease of microhardness, rms microstrain, notable increase of the thermal stability of microstructure in nanostructured $\mathrm{Ni}$ processed by HPT. Structural studies showed that GBs changed their diffraction contrast as in the case of moderate annealing, i.e. their relaxation occurred. Later studies of HPT-processed $\mathrm{Ni}$ have shown that the effect of UST is not monotonous: first an increase of the GB energy, rms strains, microhardness occurs with an increase of the UST amplitude, then all these characteristics decrease indicating on the GB relaxation [24,25]. Studies using ECAP-processed $\mathrm{Ni}$ revealed an uncommon effect of UST on mechanical properties: at stress amplitudes $50 \div 90 \mathrm{MPa}$ it resulted in a simultaneous enhancement of both the elongation to failure and ultimate strength at room temperature tensile tests [22].

In order to understand the effect of UST on the structure of UFG metals, two kinds of simulations have been carried out basing on molecular dynamics [14-19] and twodimensional dislocation dynamics [26-30].

The first molecular dynamics simulations were done for a two-dimensional model nanocrystal, in which the NGB structure was created by plastic deformation of an as-constructed atomistic model [14]. This work allowed one to predict many qualitative effects related to UST such as the relaxation of GBs, internal strains, and increase of the fraction of high-angles boundaries. All these predictions are confirmed by experimental data presented in [20,24,25].

The three-dimensional atomistic simulations were based on columnar bicrystal and nanocrystal models considered in Section 5. When oscillating stresses with the amplitudes of several gigapascals are applied, the GBs generate partial lattice dislocation, which glide across the grains and sink at the surfaces in the case of bicrystal and opposite GBs in the case of nanocrystal. In several cycles of loading, the GBs become free of EGBDs and acquire an equilibrium structure, which does not cause long-range internal stresses. As an example, Fig. 5 presents an atomic energy map for the nanocrystal whose energy map was given in Fig. 3a [19]. The GB relaxation occurred here by a generation and movement of partial lattice dislocations that resulted in a curved shape of GBs and formation of stacking faults, which are visualized in the figure by gray lattice atoms having a slightly higher energy than the one of white f.c.c. lattice atoms. Nevertheless, the structure given in Fig. 5 has an energy similar to that of a nanocrystal with equilibrium GBs.

Thus, the molecular dynamics simulations have shown that NGBs can relax and acquire equilibrium structures under cyclic straining by a mechanism of lattice dislocation generation. This process has a threshold character

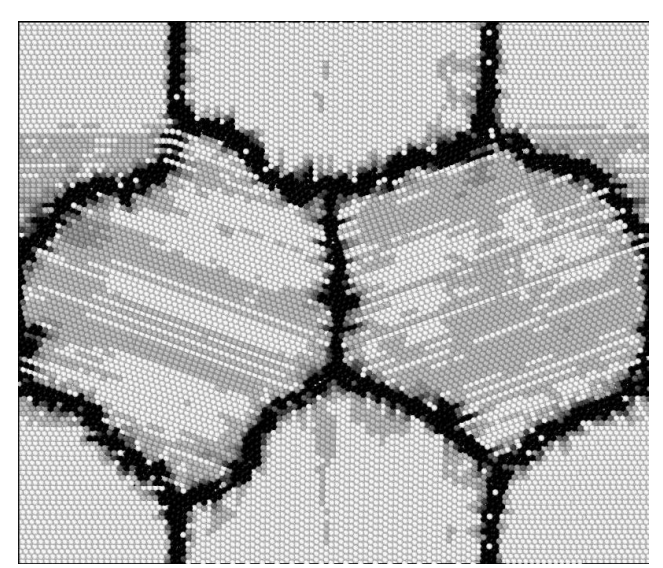

Fig. 5. Atomic stress map of [112] columnar nanocrystal of Ni with initially nonequilibrium structure after straining by 10 cycles with stress amplitude $4 \mathrm{GPa}$. 
[15 - 17,19] and can occur only at stress amplitudes higher that a certain critical value. Obviously, this mechanism is caused by a reduction of the stress necessary for dislocation emission from NGBs as compared to equilibrium GBs. The enhancement of dislocation emission by GBs due to their deformation distortions has been recently predicted on the basis of continuum theory of dislocations [80].

Discrete dislocation simulations of the relaxation in a system of edge dislocations in a model quasi-two-dimensional grain, the junctions of which contain Rybin disclinations, have been carried out in [26-30]. It is assumed that this is a probe grain in a deformed polycrystal the other grains of which are considered as an effective medium, which is not deformed plastically, but accepts all elastic fields of defects. The GBs are nontransparent for dislocations, i.e. any dislocation entering a GB is trapped there. Two cases have been considered when the dislocations belong to a single [26-29] or three [30] slip systems. The basic idea for this study, which was first proposed in [21] is that under a combined effect of the ultrasound and junction disclinations the dislocations could enter the GBs or rearrange to form low-angle boundaries cancelling the disclinations.

Indeed, the discrete dislocation simulations have shown that under oscillating stresses the dislocations can move to GBs and trap there. These dislocations have the signs opposite to the ones of EGBDs which constitute the disclination quadrupole and this process always results in a cancellation of the disclinations. In the case of multiple slip systems the mutual interactions of lattice dislocations play an important role. If the amplitude of stresses is low and density of dislocations is high, the latter form a substructure consisting of finite tilt boundaries. An example is given in Fig. 6, where the distribution of 300 hundred dislocations in the initial state (a) and after the action of five thousand cycles of oscillating shear stress with different amplitudes (b,c) are presented [30]. Here, the amplitude is determined by a certain dimensionless parameter $K$, which appears during the normalization of dislocation movement equations. With an increase of parameter $K$, more and more dislocations reach the boundaries and less dislocations form substructure. The intermediate structures (b, c) result in a slight increase of the rms stresses in the grain, i.e. in a higher elastic energy of the system, while at higher amplitudes corresponding to Fig. 6d, the internal stress field of the total system of defects is significantly lower that in the initial state [30].

These simulations show that relaxation of the nonequilibrium structure of GBs in severely deformed nanostructured materials under ultrasound actions can occur also by trapping of lattice dislocations at GBs. This is possible, if there are sufficient dislocations in the grains or dislocation sources can operate under the ultrasound. Multiplication of dislocations during UST of ordinary materials is observed at stress amplitudes less than $10 \mathrm{MPa}$ [81], therefore, in UFG metals dislocation generation can be expected at stresses of several dozens of megapascals. Increase of internal strains

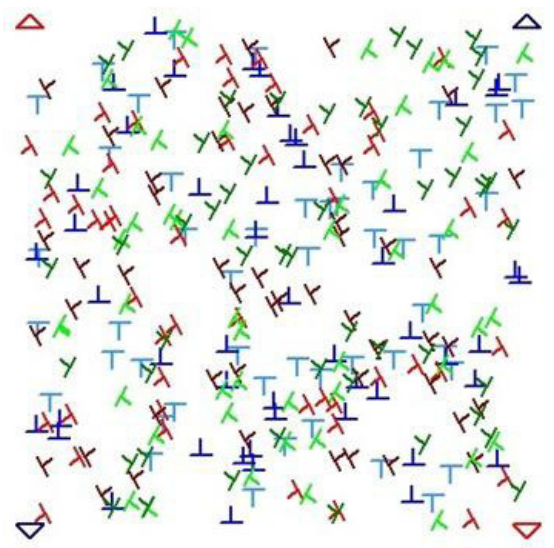

a

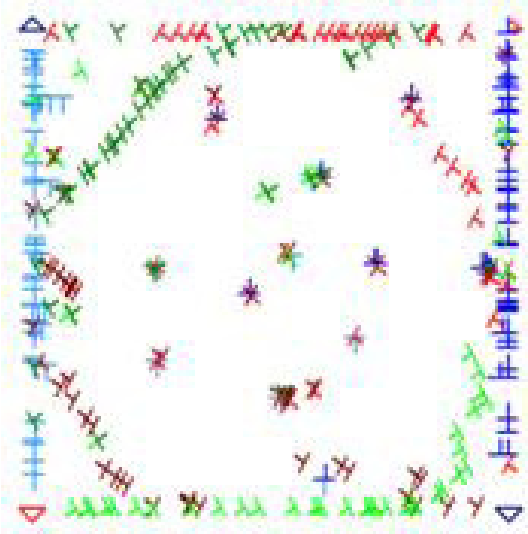

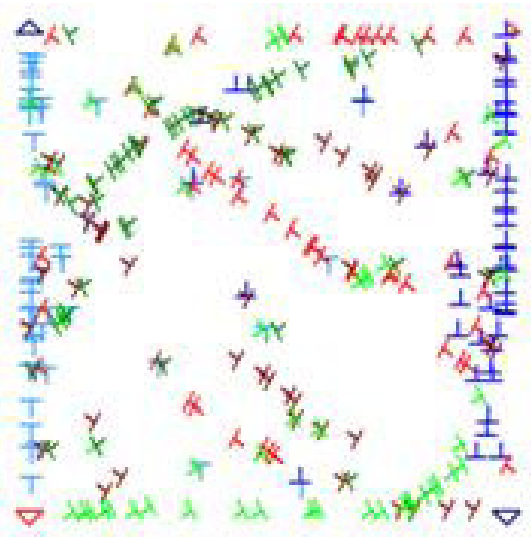

b

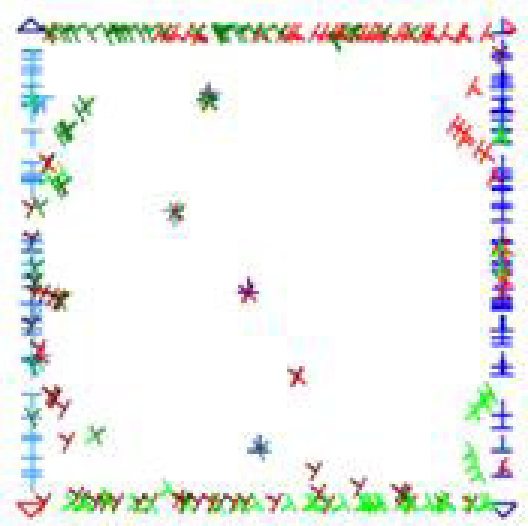

d

Fig. 6. Distribution of edge dislocations of three slip systems in a quasi-two-dimensional grain with a junction disclination quadrupole in the initial state (a) and after 5000 cycles of shear stress oscillations with dimensionless amplitude of $K=0.3$ (b), 0.5 (c) and 1.0 (d). 
in experiments reported in [24,25] occurs at about $30 \mathrm{MPa}$. Therefore, the observed behavior of an increase of internal stresses followed by relaxation with an increase of the UST amplitude can be explained by the interaction of lattice dislocations and NGBs.

Thus, the results of experimental and computer simulation studies of the effect of high frequency cyclic stresses are in good mutual agreement and demonstrate that UST can serve as an efficient alternative to annealing to equilibrate the structure of SPD-processed UFG materials and modify their mechanical properties.

In [22] the following qualitative comparison between the effects of annealing and UST was proposed. The thermodynamic state of an as-prepared UFG metal can be considered as a point in the phase space. Phase trajectories of the system during annealing and UST start from this point but in general will be different. Therefore, UST can lead the system to states, which are not accessible by annealing. The final configurations of the system in the two cases will be also different and this will cause different properties of the UFG materials after these treatments. Of course, a combination of annealing and UST can lead to even a wider variety of ways of structure and property modification.

\section{Concluding remarks}

In the present paper, we have reviewed the recent progress in experimental and theoretical studies of NGBs in SPDprocessed materials in connection with earlier developed models. We have found that in general, these results are in a good agreement and at present allow one to construct realistic atomistic models. These models can now be applied to study the effect of NGB structure on mechanical, diffusion properties of UFG metals. Moreover, the nonequilibrium state can be quantified in terms of long-range stresses and energies through atomistic calculations.

The concept of nonequilibrium grain boundaries can be useful not only for bulk, but also for two-dimensional nanomaterials. For instance, NGBs with disordered networks of disclination dipoles has been recently analyzed in grapheme [82].

Affecting the nonequilibrium structure of GBs, ultrasonic treatment of UFG materials can give a new tool for a modification of the properties of these materials and allow for obtaining combinations of properties, which can be different from those obtainable by ordinary treatments, for example, by annealing.

In general, we can state, in addition to conclusions of a recent review [12], that grain boundary engineering based on a control of the nonequilibrium structure of GBs through various methods can provide new possibilities for obtaining new extraordinary properties of UFG and nanostructured materials.

Acknowledgements. The present work was supported by the state assignment of IMSP RAS (in part concerning the nonequilibrium GB structure) and by the Russian Science Foundation, Grant No. 16-19-10126 (in part related to a study of oscillating stress effects).

\section{References}

1. P. H. Pumphrey, H. Gleiter. Philos. Mag. 32, 881 (1975). DOI: $10.1080 / 14786437508221629$

2. R.Z. Valiev, V. Yu. Gertsman, O. A. Kaibyshev. Phys. Status Solidi A. 78, 97 (1983). DOI: 10.1002/pssa.2210780121

3. R. Z. Valiev, V. Yu. Gertsman, O. A. Kaibyshev. Phys. Status Solidi A. 97, 11 (1986). DOI: 10.1002/pssa.2210970102

4. A.A. Nazarov, A.E. Romanov, R.Z. Valiev. Acta Metall. Mater. 41, 1033 (1993). DOI: 10.1016/0956-7151(93)90152-I

5. D. J. Dingley, R.C. Pond. Acta Metall. 27, 667 (1979). DOI: 10.1016/0001-6160(79)90018-X

6. R.Z. Valiev, A. V. Korznikov, R. R. Mulyukov. Phys. Metals Metallogr. 73, 70 (1992).

7. R.Z. Valiev, A.V. Korznikov, R.R. Mulyukov. Mater. Sci.Eng. A 168, 141 (1993). DOI: 10.1016/0921-5093(93)90717-S

8. N.I. Noskova, R. R. Mulyukov. Submicrocrystalline and nanocrystalline metals and alloys. Ekaterinburg, Ural Branch RAS (2003) 279 p. (in Russian) [Н. И. Носкова, P.P. Мулюков. Субмикрокристаллические и нанокристаллические металлы и сплавы. Екатеринбург, УрО PAH (2003) 279 c.]

9. R.R. Mulyukov, A.A. Nazarov, R.M. Imayev. Mater. Sci. Forum. 584-586, 29 (2008). DOI: 10.4028/www.scientific.net/MSF.584-586.29

10. R.Z. Valiev, A.P. Zhilyaev, T.G. Langdon. Bulk nanostructured materials: fundamentals and applications. Wiley, Hoboken (2013) 440 p.

11. A.A. Nazarov, R.R. Mulyukov. In: Handbook of Nanoscience, Engineering, and Technology (Eds. W. Goddard, D. Brenner, S. Lyshevski, G. Iafrate). CRC Press, Boca Raton (2003). P. 22-1-22-41.

12. X. Sauvage, G. Wilde, S. V. Divinsky, Z. Horita, R.Z. Valiev. Mater. Sci.Eng. A. 540, 1 (2012). DOI: 10.1016/j.msea.2012.01.080

13. P. Kumar, M. Kawasaki, T. G. Langdon. J. Mater. Sci. 51, 7 (2016). DOI: 10.1007/s10853-015-9143-5

14. A.A. Nazarova, S.V. Dmitriev, Y.A. Baimova, R. R. Mulyukov, A.A. Nazarov. Phys. Metals Metallogr. 111, 513 (2011). DOI: 10.1134/S0031918X11040090

15. A. A. Nazarov. Rev. Adv. Mater. Sci. 47, 42 (2016).

16. A. A. Nazarov. Letters on Materials. 6(3), 179 (2016). DOI: $10.22226 / 2410-3535-2016-3-179-182$

17. A. A. Nazarov, R. T. Murzaev. J. Metast. Nanocr. Mater. 30, 1 (2018). DOI: 10.4028/www.scientific.net/JMNM.30.1

18. A. A. Nazarov, R. T. Murzaev. Letters on materials. 8(1), 5 (2018). DOI: $10.22226 / 2410-3535-2018-1-5-10$

19. A. A. Nazarov, R. T. Murzaev. Comp. Mater. Sci. 151, 204 (2018). DOI: 10.1016/j.commatsci.2018.05.015

20. A.A. Nazarova, R.R. Mulyukov, Yu. V. Tsarenko, V.V. Rubanik, A.A. Nazarov. Mater. Sci. Forum. 667-669, 605 (2011). DOI: 10.4028/www.scientific.net/MSF.667-669.605

21. A.A. Nazarov, A.A. Samigullina, R.R. Mulyukov, Yu. V. Tsarenko, V.V. Rubanik. J. Machinery Manuf. Reliability. 43, $153 \quad$ (2014). DOI: $10.3103 /$ S1052618814020113

22. A. A. Samigullina, A.A. Nazarov, R. R. Mulyukov, 
Yu. V. Tsarenko, V. V. Rubanik. Rev. Adv. Mater. Sci. 39, 48 (2014).

23. A.A. Samigullina, R.R. Mulyukov, A.A. Nazarov, A.A. Mukhametgalina, Y.V. Tsarenko, V.V. Rubanik. Letters on materials. 4(1), 52 (2014). (in Russian) [А.А. Самигуллина, Р.Р. Мулюков, А.А. Назаров, А. А. Мухаметгалина, Ю.В. Царенко, В.В. Рубаник. Письма о материалах. 4(1), 52 (2014).] DOI: 10.22226/2410-3535-2014-1-52-54

24. A. A. Mukhametgalina, A. A. Samigullina, S. N. Sergeyev, A.P. Zhilyaev, A.A. Nazarov, Yu.R. Zagidullina, N. Yu. Parkhimovich, V.V. Rubanik, Yu. V. Tsarenko. Letters on materials. 7(2), 85 (2017). (in Russian) [А.А. Мухаметгалина, А.А. Самигуллина, С.Н. Сергеев, А.П. Жиляев, А.А. Назаров, Ю.Р. Загидуллина, Н. Ю. Пархимович, В.В. Рубаник, Ю. В. Царенко. Письма о материалах. 7(2), 85 (2017).] DOI: $10.22226 / 2410-3535-2017-2-85-90$

25. A.A. Samigullina, A.A. Mukhametgalina, S.N. Sergeyev, A.P. Zhilyaev, A.A. Nazarov, Yu. R. Zagidullina, N. Yu. Parkhimovich, V. V. Rubanik, Yu. V. Tsarenko. Ultrasonics. 82, 313 (2018). DOI: 10.1016/j.ultras.2017.09.005

26. D. V. Bachurin, R.T. Murzaev, J.A. Baimova, A. A. Samigullina, K. A. Krylova. Letters on Materials. 6(3), 183 (2016). (in Russian) [Д.В. Бачурин, Р.Т. Мурзаев, Ю.А. Баимова, А.А. Самигуллина, К. А. Крылова. Письма о материалах. 6(3), 183 (2016).] DOI: $10.22226 / 2410-3535-2016-3-183-188$

27. R.T. Murzaev, D. V. Bachurin, A.A. Nazarov. Phys. Metals Metallogr. 118, 621 (2017). DOI: $10.1134 /$ S0031918X17070079

28. D. V. Bachurin, R.T. Murzaev, A.A. Nazarov. Modelling Simul. Mater. Sci. Eng. 25, 085010 (2017). DOI: 10.1088/1361-651X/aa9199

29. R. T. Murzaev, D. V. Bachurin, A.A. Nazarov. Phys. Metals Metallogr. 118, 621 (2017). DOI: $10.1134 /$ S0031918X17070079

30. R. T. Murzaev, D. V. Bachurin, A.A. Nazarov. Int.J. Solids Structures, accepted (2018). DOI: 10.1016/j.ijsolstr.2018.06.007

31. A. Hasnaoui, H. Van Swygenhoven, P.M. Derlet. Acta Mater. 50, 3927 (2002). DOI: 10.1016/S1359-6454(02)00195-7

32. G. J. Tucker, D. L. McDowell. Int. J. Plast. 27, 841 (2011). DOI: 10.1016/j.ijplas.2010.09.011

33. T. J. Rupert, C. A. Schuh. Philos. Mag. Lett. 92, 20 (2012). DOI: 10.1080/09500839.2011.619507

34. V.V. Rybin, A.A. Zisman, N. Yu. Zolotarevskii. Phys. Solid State. 27, 181 (1985).

35. V.V. Rybin. Large plastic deformations and fracture of metals. Metallurgiya, Moscow (1986) 224 p. (in Russian) [B.В. Рыбин. Большие пластические деформации и разрушение металлов. Москва, Металлургия (1986) 224 c.]

36. V.V. Rybin, A.A. Zisman, N. Yu. Zolotarevskii. Acta Metall. Mater. 41, 2211 (1993). DOI: 10.1016/0956-7151(93)90390-E

37. A.E. Romanov, A.L. Kolesnikova. Progr. Mater. Sci. 54, 740 (2009). DOI: 10.1016/j.pmatsci.2009.03.002
38. T. S. Orlova, A. A. Nazarov, N. A. Enikeev, I. V. Alexandrov, R.Z. Valiev, A.E. Romanov. Phys. Solid State 47, 845 (2005). DOI: 10.1134/1.1924843

39. T. S. Orlova, A.E. Romanov, A. A. Nazarov, N. A. Enikeev, I. V. Alexandrov, R.Z. Valiev. Techn. Phys. Lett. 31, 1015 (2005). DOI: 10.1134/1.2150885

40. A. A. Nazarov, N.A. Enikeev, T. S. Orlova, A. E. Romanov, I. V. Alexandrov, I. J. Beyerlein, R. Z. Valiev. Acta Materialia. 54, 985 (2006). DOI: 10.1016/j.actamat.2005.10.025

41. G. F. Sarafanov, V. N. Perevezentsev. Techn. Phys. Lett. 35, 302 (2009). DOI: 10.1134/S106378500904004X

42. V.V. Rybin, V.N. Perevezentsev, Yu. V. Svirina. Techn. Phys. 61, 898 (2016). DOI: 10.1134/S1063784216060190

43. V.V. Rybin, V.N. Perevezentsev, Yu. V. Svirina. Phys. Metals Metallogr. 118, (2017) 1171. DOI: $10.1134 /$ S0031918X17120110

44. V.V. Rybin, V.N. Perevezentsev, Yu. V. Svirina. Techn. Phys. 62, 745 (2017). DOI: 10.1134/S1063784217050255

45. T. Simokawa, T. Yamashita, T. Niiyama, N. Tsuji. Mater. Trans. 57, 1392 (2016). DOI: $10.2320 /$ matertrans.MH201518

46. R.Z. Valiev, R. Sh. Musalimov. Phys. Metals Metallogr. 78, 666 (1994).

47. Z. Horita, D. J. Smith, M. Nemoto, R.Z. Valiev, T.G. Langdon. J. Mater. Res. 13, 446 (1998). DOI: 10.1557/JMR.1998.0057

48. M. P. Liu, H. J. Roven, X. T. Liu, M. Murashkin, R. Z. Valiev, T. Ungár, L. Balogh. Trans. Nonferrous Metals Soc. China 20, 2051 (2010). DOI: 10.1016/S1003-6326(09)60416-7

49. H. Rösner, C. Kübel, Y. Ivanisenko, L. Kurmanaeva, S. V. Divinski, M. Peterlechner, G. Wilde. Acta Mater. 59, 7380 (2011). DOI: 10.1016/j.actamat.2011.08.020

50. K. Reimann, R. Würschum. J. Appl. Phys. 81, 7186 (1997). DOI: $10.1063 / 1.365307$

51. P. G. Sanders, A. B. Witney, J.R. Weertman, R.Z. Valiev, R.W. Siegel. Materials Sci.Eng. A. 204, 7 (1995). DOI: 10.1016/0921-5093(95)09928-X

52. E. Hellstern, H. J. Fecht, Z. Fu, W.L. Johnson. J. Appl. Phys. 65, 305 (1989). DOI: 10.1063/1.342541

53. J. Languillaume, F. Chmelik, G. Kapelski, F. Bordeaux, A. A. Nazarov, G. Canova, C. Esling, R.Z. Valiev, B. Baudelet. Acta Metall. Mater. 41, 2953 (1993). DOI: 10.1016/0956-7151(93)90110-E

54. E. Korznikova, E. Schafler, G. Steiner, M. J. Zehetbauer. In: Ultrafine Grained Materials IV (Eds.Y. T. Zhu, T. G. Langdon, Z. Horita, M. J. Zehetbauer, S. L. Semiatin, T. C. Lowe). TMS, Warrendale, USA (2006) P. 97 - 102.

55. A.P. Zhilyaev, B.-K. Kim, J.A. Szpunar, M.D. Baro, T.G. Langdon. Mater. Sci.Eng. A. 391, 377 (2005). DOI: 10.1016/j.msea.2004.09.030

56. P. V. Kuznetsov, T. V. Rakhmatulina, I. V. Belyaeva, A. V. Korznikov. Phys. Metals Metallogr. 118, 241 (2017). DOI: 10.1134/S0031918X17030115

57. Yu. R. Kolobov, G.P. Grabovetskaya, M.B. Ivanov, A. P. Zhilyaev, R.Z. Valiev. Scripta Mater. 44, 873 (2001). DOI: 10.1016/S1359-6462(00)00699-0

58. R. Würschum, A. Kübler, S. Gruß, P. Scharwaechter, W. Frank, R.Z. Valiev, R. R. Mulyukov, H.-E. Schaefer. Ann. Chim.-Sci. Matér. 21, 471 (1996).

59. V.V. Popov, A. V. Sergeev. Phys. Metals. Metallogr. 118, 
1091 (2017). DOI: 10.1134/S0031918X17110126

60. S. V. Divinsky, G. Reglitz, H. Rösner, Y. Estrin, G. Wilde. Acta Mater. 59, 1974 (2011). DOI: $10.1016 /$ j.actamat.2010.11.063

61. G. Wilde, J. Ribbe, G. Reglits, M. Wegner, H. Rösner, Y. Estrin, M. Zehetbauer, D. Setman, S. Divinsky. Adv.Eng. Mater. 12, 758 (2010). DOI: 10.1002/adem.200900333

62. A. A. Nazarov, A. E. Romanov, R. Z Valiev. Nanostr. Mater. 6, 775 (1995). DOI: 10.1016/0965-9773(95)00174-3

63. A. A. Nazarov, A. E. Romanov, R. Z Valiev. Scripta Mater. 34, 729 (1996). DOI: 10.1016/1359-6462(95)00573-0

64. A.A. Nazarov. Scripta Mater. 37, 1155 (1997). DOI: 10.1016/S1359-6462(97)00230-3

65. A. A. Nazarov, A.E. Romanov, R. Z Valiev. Nanostr. Mater. 4, 93 (1994). DOI: 10.1016/0965-9773(94)90131-7

66. A. A. Nazarov, A.E. Romanov, B. Baudelet. Philos. Mag. Lett. 68, 303 (1993). DOI: 10.1080/09500839308242907

67. A. A. Nazarov. Ann. Chim.-Sci. Matér. 21, 461 (1996).

68. J. Hirth, J. Lothe. Theory of dislocations. Wiley, New York (1982).

69. A.E. Romanov, V.I. Vladimirov. In: Dislocations in Crystals (Ed.F. R.N. Nabarro). North Holland, Amsterdam (1992). P. $191-402$.

70. A. I. Mikhailin, A.E. Romanov. Sov. Phys. Solid State 28, 337 (1986).

71. L. V. Zhigilei, A.I. Mikhailin, A.E. Romanov. Fizika metallov i metallovedenie. 66, 65 (1988). (in Russian) [Л.В. Жигилей, А. И. Михайлин, А. Е. Романов. ФММ.
66, 65 (1988).]

72. K. Zhou, A. A. Nazarov, M. S. Wu. Phys. Rev. B. 73, 045410 (2006). DOI: 10.1103/PhysRevB.73.045410

73. M. S. Wu, K. Zhou, A. A. Nazarov. Phys. Rev. B. 76, 134105 (2007). DOI: 10.1103/PhysRevB.76.134105

74. M. S. Wu, K. Zhou, A. A. Nazarov. Modell. Simul. Mater. Sci. Eng. 14, 1 (2006). DOI: 10.1088/0965-0393/14/4/008

75. K. Zhou, A. A. Nazarov, M. S. Wu. Phys. Rev. Lett. 98, 035501 (2007). DOI: 10.1103/PhysRevLett.98.035501

76. K. Zhou, M.S. Wu, A.A. Nazarov. Acta Mater. 56, 5828 (2008). DOI: 10.1016/j.actamat.2008.07.059

77. A. A. Nazarov. Interface Sci. 8, 315 (2000). DOI: 10.1023/A:1008720710330

78. D. V. Bachurin, A.A. Nazarov. Philos. Mag. 83, 2653 (2004). DOI: $10.1080 / 1478643031000137895$

79. I. Kaur, W. Gust, L. Kozma. Handbook of Grain Boundary and Interphase Boundary Diffusion Data. Ziegler Press, Stuttgart (1989).

80. I. A. Ovid'ko, A. G. Sheinerman, R. Z. Valiev. Scripta Mater. 76, 45 (2014). DOI: 10.1016/j.scriptamat.2013.12.012

81. N.A. Tyapunina, E.K. Naimi, G.M. Zinenkova. Ultrasound action on crystals with defects. MSU, Moscow (1999) 238 p. (in Russian) [Н. А. Тяпунина, Е. К. Наими, Г.М. Зиненкова. Действие ультразвука на кристаллы с дефектами. Москва, Изд-во Моск. ун-та (1999) 238 c.]

82. A.E. Romanov, A.L. Kolesnikova, T.S. Orlova, I. Hussainova, V.E. Bougrov, R. Z. Valiev. Carbon. 81, 223 (2015). DOI: 10.1016/j.carbon.2014.09.053 